\section{Guidelines TO THE \\ Practice of ANesthesia}

Revised Edition 2017

Canadian Journal of Anesthesia

Volume 64, Number 1

How does this statement differ from the 2016

Guidelines? A significant change has been implemented and is highlighted in the text. It relates to more specific recommendations for the use of realtime ultrasound for the placement of internal jugular central venous catheters and the additional recommendation that ultrasound must also be available to assist with arterial cannulations.

\section{GuIDE D'EXERCICE DE L'ANESTHÉSIE} Édition révisée 2017

Journal canadien d'anesthésie Volume 64, numéro 1

Comment cet énoncé diffère-t-il des Lignes directrices de 2016? Une modification majeure a été introduite et est mise en évidence dans le texte. Il s'agit de recommandations plus spécifiques concernant l'utilisation de l'échoguidage en temps réel pour positionner les cathéters veineux centraux jugulaires internes ainsi qu'une recommandation supplémentaire qui préconise que l'échoguidage devrait également être disponible lorsqu' on réalise une canulation artérielle. 


\section{Contents}

Preamble

Basic principles

Organization of anesthetic services

Responsibilities of the chief of anesthesia

Privileges in anesthesia

Fitness to practice

Residents

Ancillary help

Anesthetic equipment and anesthetizing location

The pre-anesthetic period

The anesthetic period

Records

Patient monitoring

The post-anesthetic period

Recovery facility

Discharge of patients after day surgery

Guidelines for obstetric regional analgesia

Initiation of obstetric regional analgesia

Maintenance of regional analgesia during labour

Oral intake during labour

Guidelines for acute pain management using neuraxial analgesia

Administrative and educational policies

Policies for drug administration

Patient monitoring and management of adverse events

Guidelines for the practice of anesthesia outside a hospital facility

Patient selection

Preoperative considerations

Conduct of anesthesia

Appendix 1: Canadian Standards Association—standards for equipment

Appendix 2: American Society of Anesthesiologists' classification of physical status

Appendix 3: Pre-anesthetic checklist

Appendix 4: Guidelines, standards, and other official statements available on the internet

Appendix 5: Position Paper on Anesthesia Assistants: An Official Position

Paper of the Canadian Anesthesiologists' Society

Appendix 6: Position paper on procedural sedation: An Official Position

Paper of the Canadian Anesthesiologists' Society 


\section{Table des matières}

Préambule

Principes de base

Organisation des services d'anesthésie

Responsabilités du chef du département d'anesthésie

Privilèges d'exercice en anesthésie

Aptitude à la pratique

Résidents

Personnel de soutien

Matériel d'anesthésie et lieux convenant à l'anesthésie

La période préanesthésique

La période anesthésique

Dossiers

Monitorage du patient

La période postanesthésique

La salle de réveil

Congé des patients après chirurgie d'un jour

Lignes directrices pour l'analgésie régionale en obstétrique

Éléments requis pour l'utilisation de l'analgésie régionale en obstétrique

Maintien de l'analgésie régionale pendant le travail

Absorption orale pendant le travail

Lignes directrices pour la prise en charge de la douleur aiguë à l'aide de l'analgésie neuraxiale

Politiques administratives et éducatives

Politiques en matière d'administration de médicaments

Monitorage des patients et prise en charge des événements indésirables

Lignes directrices pour l'exercice de l'anesthésie hors du milieu hospitalier

Sélection des patients

Considérations préopératoires

Conduite de l'anesthésie

Annex 1: Normes de l'Association canadienne de normalisation (CSA) au sujet de l'équipement

Annexe 2: Classification de l'état de santé des patients, selon

l'American Society of Anesthesiologists

Annexe 3: Liste de vérification préanesthésique

Annexe 4: Lignes directrices, normes et autres énoncés officiels disponibles sur l'internet

Annexe 5: Exposé de principe sur les assistants en anesthésie: exposé de principe officiel de la Société canadienne des anesthésiologistes

Annexe 6: Exposé de principe sur la sédation consciente: exposé de principe officiel de la Société canadienne des anesthésiologistes 


\title{
Guidelines to the Practice of Anesthesia - Revised Edition 2017
}

\author{
Gregory Dobson, MD • Matthew Chong, MD • Lorraine Chow, MD • \\ Alana Flexman, MD • Matthew Kurrek, MD • Claude Laflamme, MD • \\ Annie Lagacée, MD · Shean Stacey, MD • Barton Thiessen, MD
}

Published online: 11 November 2016

(c) Canadian Anesthesiologists' Society 2016

Overview The Guidelines to the Practice of Anesthesia Revised Edition 2017 (the guidelines) were prepared by the Canadian Anesthesiologists' Society (CAS), which reserves the right to determine their publication and distribution. Because the guidelines are subject to revision, updated versions are published annually. The Guidelines to the Practice of Anesthesia Revised Edition 2017 supersedes all previously published versions of this document. Although the CAS encourages Canadian anesthesiologists to adhere to its practice guidelines to ensure high-quality patient care, the society cannot guarantee any specific patient outcome. Each anesthesiologist should exercise his or her own professional judgement in determining the proper course of action for any patient's circumstances. The CAS assumes no responsibility or liability for any error or omission arising from the use of any information contained in its Guidelines to the Practice of Anesthesia.

\section{Preamble}

Anesthesia is a dynamic specialty of medicine. Continuous progress is being made to improve anesthetic care for patients undergoing surgical and obstetric procedures in Canada. To reflect this progress in the delivery of

Electronic supplementary material The online version of this article (doi:10.1007/s12630-016-0749-0) contains supplementary material, which is available to authorized users.

G. Dobson, MD $(\bowtie) \cdot$ M. Chong, MD - L. Chow, MD .

A. Flexman, MD · M. Kurrek, MD - C. Laflamme, MD .

A. Lagacée, MD - S. Stacey, MD - B. Thiessen, MD

Canadian Anesthesiologists' Society, 1 Eglinton Avenue East,

Suite 208, Toronto, ON M4P 3A1, Canada

e-mail: standards@cas.ca anesthetic services, this document is reviewed annually and revised periodically.

The following recommendations are aimed at providing basic guidelines to anesthetic practice. They are intended to provide a framework for reasonable and acceptable patient care and should be so interpreted, allowing for some degree of flexibility in different circumstances. Each section of these guidelines is subject to revision as warranted by the evolution of technology and practice.

\section{Basic Principles}

In this document, the term anesthesiologist is used to designate all licensed medical practitioners with privileges to administer anesthetics. An anesthetic is any procedure that is deliberately performed to render a patient temporarily insensitive to pain or the external environment so that a diagnostic or therapeutic procedure can be performed.

These guidelines are intended to apply to all anesthesiologists in Canada. The independent practice of anesthesia is a specialized field of medicine. As such, it should be practised by physicians with appropriate training in anesthesia. The only route to specialist recognition in anesthesia in Canada is through the certification process of the Royal College of Physicians and Surgeons of Canada. The Canadian Anesthesiologists' Society (CAS) acknowledges the fact that remote communities often lack the population base to support a specialist anesthetic practice. In these communities, appropriately trained family physicians may be required to provide anesthesia services. Communities which have the clinical volume to support full-time anesthesiologists should have fellowshipcertified anesthesiologists providing those services. All anesthesiologists should continue their education in the 
practice of anesthesia, pain management, perioperative care, and resuscitation.

\section{Organization of Anesthetic Services}

The department of anesthesia should be properly organized, directed, and integrated with other departments in the organization or facility, and it should include all facility staff members who provide anesthetic services to patients for surgical, obstetric, diagnostic, and therapeutic purposes.

The department should be staffed appropriately, bearing in mind the scope and nature of the services provided, and it should strive to ensure that these services are available as required by the health care facility.

The chief of the department should be a physician who has obtained certification or appropriate training in anesthesia. This individual should be appointed in the same manner as other chiefs of clinical departments and should be a member of the senior medical administrative bodies for the facility.

\section{Responsibilities of the Chief of Anesthesia}

1. To be aware of the current CAS Guidelines to the Practice of Anesthesia, the requirements of the Canadian Council on Health Services Accreditation, and the requirements of the provincial licensing authority as they relate to anesthesia;

2. To ensure that written policies with respect to the practice of anesthesia are established and enforced;

3. To evaluate the qualifications and abilities of the physicians providing anesthetic care and other health professionals providing ancillary care-this includes (but is not restricted to) the recommendations of clinical privileges for physicians with anesthetic responsibilities and annual review of these privileges;

4. To monitor systematically the quality of anesthetic care provided throughout the health care facility-this should include chart reviews and internal audits or more detailed reviews when indicated;

5. To ensure that records are kept for all anesthetic procedures-these records should allow for evaluation of all anesthetic care in the facility;

6. To carry out such other duties as the governing body of the facility may delegate to ensure safe anesthetic care;

7. To promote institutional compliance with applicable Canadian Standards Association (CSA) Standards (Appendix 1); and

8. To coordinate liaison between the departments of anesthesiology, biomedical engineering, and information management services.
Privileges in Anesthesia

All physicians applying for privileges in anesthesia should demonstrate satisfactory completion of specialist postgraduate training in anesthesia. Such training in university programs approved by the Royal College of Physicians and Surgeons of Canada is the standard; international medical graduates approved for licensure by provincial regulatory bodies should demonstrate training equivalent to the Canadian standard. Family physicians practicing anesthesia should demonstrate satisfactory completion of a specific postgraduate training program of at least a one-year duration. Special areas of anesthesia care may have specific concerns. Privileges in pediatric anesthesia may be determined in each institution by the Department of Anesthesia according to the pediatric population they serve, the child's age and the presence of comorbidities, the physician's specific training and experience in pediatric anesthesia, and the complexity of the procedure involved.

Physicians with anesthetic privileges should possess the knowledge, technical, and non-technical skills necessary for the practice of anesthesia.

Technical/knowledge based skills include the ability:

- To provide pre-anesthetic evaluation of the patient and determine appropriate anesthetic management;

- To render the patient insensible to pain for the performance of diagnostic and therapeutic procedures, surgical operations and obstetric procedures;

- To monitor and support the vital organ systems during the perioperative period;

- To provide immediate post-anesthetic management of the patient;

- To provide resuscitation and intensive care when indicated;

- To provide relief from acute and chronic pain.

Non-technical skills include:

- Task management: planning and preparing, prioritising, providing and maintaining standards, identifying and utilising resources;

- Team working: co-ordinating activities with team members, exchanging information, using authority and assertiveness, assessing capabilities, supporting others, supporting the WHO Surgical Safety Checklist;

- Situation awareness: gathering information, recognising and understanding, anticipating;

- Decision making: identifying options, balancing risks and selecting options, re-evaluating.

Fitness to Practice

The provision of anesthesia care requires that anesthesiologists have a high level of expertise combined 
with sound judgment, as well as the ability to recognize and respond to changing clinical situations despite sometimes adverse personal physical circumstance. Anesthesia departments must recognize that optimal care is provided by fit anesthesia practitioners. Anesthesia departments therefore have an obligation to develop policies, which, as far as possible, ensure that practitioners are healthy and fit to undertake their duties of practice.

Health and fitness for duty are impaired by a variety of factors, including adverse physical conditions, mental impairment, and fatigue. All of these factors impair fitness and the ability to recognize and respond appropriately to often rapidly changing clinical circumstances. Many studies have demonstrated that fatigue impairs judgment and psychomotor performance in a manner similar to drugs or alcohol. Shifting circadian rhythms, aging, and lack of sleep reinforce such problems; a fatigue-induced lack of recognition of these problems can compound the potential for errors in such circumstances. Physical impairment, illness and severe stress can have similar detrimental effects on performance.

Anesthesia departments and individual anesthesiologists have a responsibility to organize their working duties in such a fashion that ensures illness and fatigue do not regularly affect clinical duties. Individual rosters must allow adequate rest between working shifts and daily rosters should allow appropriate breaks for physiological needs, nutrition and mental fitness. Operating room scheduling processes should avoid requiring anesthesiologists to undertake nonemergency procedures during unfavourable hours.

No specific prescription for working shifts and daily roster can be defined that is appropriate for every working situation; large departments have flexibility to incorporate short shifts and individual leave while small departments may not have such freedom. Nevertheless this important area of professional practice must receive ongoing consideration and attention.

\section{Residents}

Residents in anesthesia are registered medical practitioners who participate in the provision of anesthesia services both inside and outside of the operating room as part of their training. All resident activities must be supervised by the responsible attending staff anesthesiologist, as required by the Royal College of Physicians and Surgeons of Canada and the provincial and local regulatory authorities. The degree of this supervision must take into account the condition of each patient, the nature of the anesthesia service, and the experience and capabilities of the resident (increasing professional responsibility). At the discretion of the supervising staff anesthesiologist, residents may provide a range of anesthesia care with minimal supervision. In all cases, the supervising attending anesthesiologist must remain readily available to give advice or assist the resident with urgent or routine patient care. Whether supervision is direct or indirect, close communication between the resident and the responsible supervising staff anesthesiologist is essential for safe patient care. Each anesthesia department teaching anesthesia residents should have policies regarding their activities and supervision.

\section{Ancillary Help}

The health care facility must ensure that ancillary personnel are available as assistants to the anesthesiologist. Such assistants must be available at all times and places where anesthesia services are provided. Ancillary help should have the competencies to meet the specific needs of subspecialty areas of anesthesia, reflecting on the need for specific skills in areas such as specialty pediatric anesthesia.

It is preferred that a facility will have a formally designated "Anesthesia Assistant" (AA). Such personnel must have completed specific training in anesthesia assistance. The scope of practice for AA's working in a specific institution must be approved by the Department of Anesthesia and the appropriate administrative bodies. Furthermore, AA's, like other facility employed health professionals, must be covered by the facility liability insurance. Duties and tasks delegated to AA's must be consistent with existing governmental regulations, the policies and guidelines established by professional regulatory agencies, and the policies of the local facility.

An institution without formal AA's must provide other paramedical personnel to assist the anesthesiologist. The tasks that these assistants may perform must be clearly defined. An anesthesiologist must only delegate or assign to such personnel those tasks for which they have approval or accreditation.

\section{Anesthetic Equipment and Anesthetizing Location}

An anesthetic must be administered in an appropriate facility. All necessary equipment, including emergency equipment and life support systems, medications and supplies must be readily available.

The healthcare facility, in consultation with the Department of Anesthesia, is responsible for the design and maintenance of preoperative, postoperative and anesthetising locations, as well as the purchase, maintenance and disposal of anesthetic and ancillary equipment and supplies. The Canadian Standards Association (CSA) and other standards development organizations have published standards and guidance documents for the design, construction and renovation of healthcare facilities, and for the risk management, basic safety and essential performance of medical equipment. (Appendix 1) 
The healthcare facility must ensure that:

1. The operating rooms, anesthetising locations and perioperative care locations comply to at least the minimum design and construction requirements of the national, provincial and local building, plumbing, HVAC, fire, security and electrical codes at the time of construction or renovation.

2. Medical gas and vacuum and waste anesthetic gas scavenging pipelines systems, terminal units, head walls, low pressure connecting assemblies and pressure regulators must meet the requirements of the CSA and must be certified by a CSA approved testing agency.

3. Oxygen concentrators, complying with CSA requirements are an acceptable substitute for bulk oxygen supply systems. When such concentrators are installed, users must be aware that:

a. The fraction of inspired oxygen $\left(\mathrm{FiO}_{2}\right)$ delivered by the facility medical oxygen supply may vary from 0.93 to 0.99 ;

b. Oxygen analyzers must be calibrated against $100 \% \mathrm{O}_{2}\left(\mathrm{FiO}_{2} 0.99\right)$ and room air or equivalent $\left(\mathrm{FiO}_{2}\right.$ 0.21);

c. The use of low-flow (less than $1 \mathrm{~L}$ total fresh gas flow) anesthetic techniques may result in the accumulation of inert gas (argon) and the dilution of nitrous oxide and oxygen in the circuit.

4. There is compliance with all safety regulations with respect to the storage, preparation, identification, labelling, disposal and use of medical gases, medications and related materials.

5. If general anesthesia is provided, electronic anesthetic systems should comply with CAN/CSA- C22.2 No. 60601-2-13. An alternate means of ventilation (eg manual bag and mask resuscitator) must be immediately available with each anesthesia system. The workstations shall at least be equipped with an oxygen analyser, an airway pressure monitor, waste anesthetic gas scavenging system and a high vacuum tracheal suction system with a backup means of suction. If vaporizers are used, they must use an agent-specific filling system to ensure filling with the correct agent. If a ventilator is provided, it shall have a low-pressure or disconnect alarm.

6. The equipment, supplies and appropriate assistance necessary for the safe performance of invasive procedures are provided. Diagnostic equipment, such as, but not limited to nerve stimulators, ultrasound, image intensifiers, and x-ray should be available to the anesthesiologist as required. For the placement of central venous and arterial catheters dedicated ultrasound capability must be provided by the facility. The use of real-time ultrasound guidance for elective internal jugular central venous catheter placement is strongly recommended when there has been training and experience with the technique.

7. An "Arrest Cart" containing emergency resuscitation equipment including a manual resuscitator, defibrillator complying with current Canadian Heart and Stroke Association Guidelines, and appropriate medications and intravenous equipment shall be immediately available. A "Pediatric Arrest Cart" containing pediatric resuscitation equipment must be immediately available in any location where sedation, anesthesia or resuscitation of children is performed. A length-based pediatric emergency tape kit ("Broselow ${ }^{\mathrm{TM}}$ ") may facilitate the conduct of the resuscitation process.

8. If MH-triggering agents are used, a "Malignant Hyperthermia" kit complying with the recommendations of the Malignant Hyperthermia Association of the United States shall be immediately available (Appendix 4).

9. A "Difficult Airway Kit" for difficult or failed airway management shall be immediately available. Facilities that care for children must have specialized pediatric airway equipment immediately available.

10. Facilities that care for children should have specialized pediatric equipment. Wherever obstetric anesthesia is performed, a separate area for newborn assessment and resuscitation, including designated oxygen, suction apparatus, electrical outlets, source of radiant heat, and equipment for neonatal airway management and resuscitation, shall be provided.

11. Personal protection devices, including N95 masks, facemasks and means of disposal of hazardous and infectious wastes and sharps are provided. Plume scavenging systems complying with CSA Z305.13-09 in surgical, diagnostic, therapeutic, and esthetic settings shall be provided.

12. Oxygen supplies for transport of perioperative patients must be provided. The use of transport oxygen cylinders capable of providing an audible low pressure alarm is strongly recommended.

13. All anesthetic and ancillary equipment undergoes regular inspection and maintenance by qualified personnel. Records indicating conformity to regulations and inspection and maintenance must be retained by the facility administration and the department of anesthesia.

Anesthesia providers must ensure that potentially infectious materials or agents are not transferred from one patient to another. Special attention in this regard should be given to syringes, infusion pump administration sets, and multidose drug vials.

Training on the safe use of all anesthesia equipment should be provided to all anesthesia department members prior to use. Attendance at these sessions should be 
documented. These training sessions should be repeated as necessary for new or established department members.

Recommendations for reducing occupational exposure to waste anesthetic gases:

1. Dilution ventilation at the rate of 20 exchanges $/ \mathrm{hr}$ should be provided in all anesthetising locations where volatile anesthetic gases or $\mathrm{N}_{2} \mathrm{O}$ are used.

2. Recirculation of exhaust air shall not be permitted during the hours when operations may be in progress, and it is not recommended at any other time.

3. Wherever an anesthetic delivery system is used, a scavenger shall be provided to capture anesthetic gases that might be released from the anesthetic circuit or ventilator.

4. A maintenance program shall be established in each health care facility to detect and repair leakage from the anesthetic delivery system and to maintain the effectiveness of the waste anesthetic scavenging unit.

5. The health care facility shall be responsible for conducting regular monitoring of exposure to waste anesthetic gases. The monitoring protocol should include individuals and the air flow patterns of the rooms being assessed. When $\mathrm{N}_{2} \mathrm{O}$ is used in the operating room, $\mathrm{N}_{2} \mathrm{O}$ monitoring is a suitable representation for the assessment of adequacy of scavenging.

\section{The Pre-anesthetic Period}

Policies regarding pre-anesthetic assessment should be established by the department of anesthesia.

The primary goal of pre-anesthetic assessment is to obtain the information required to plan anesthetic management. Accordingly, all aspects of the patient's medical and surgical history, findings on physical examination, and laboratory investigations that are relevant to anesthetic management should be documented by a physician who is knowledgeable about anesthetic management for the proposed diagnostic or therapeutic procedure. The patient's history should include past and current medical problems, current and recent drug therapy, unusual reactions or responses to drugs, and any problems or complications associated with previous anesthetics. A family history of adverse reactions associated with anesthesia should also be obtained. Information about the anesthetic that the patient considers relevant should also be documented. An American Society of Anesthesiologists' physical status classification (Appendix 2) should be recorded for each patient.

In appropriate cases, the availability of an "Advance Care Plan" (representation agreement, advanced directive, 'living will', 'do not resuscitate' directive, etc.) should be ascertained and it's applicability to the proposed intervention determined and documented on the anesthetic assessment record.

The surgeon may request consultation with an anesthesiologist. Medical consultations should be obtained when indicated.

Preoperative anesthetic assessment or consultation may take place in an outpatient clinic before admission for the operative procedure. Indications for pre-admission assessment include the presence of significant medical problems (co-morbidities), the nature of the proposed diagnostic or therapeutic procedure, and patient request. The presence of a parent/guardian is required if the patient is a child or not competent to provide informed consent. All patients should be informed that arrangements will be made if they wish to discuss anesthetic management with an anesthesiologist before admission to the facility. The preoperative assessment clinic should also allow for assessment of the patient by nursing and other health care personnel. The attending anesthesiologist is responsible for performing a final pre-anesthetic assessment in the immediate preoperative period.

Laboratory testing should not be performed on a routine basis and only obtained when results will change perioperative management. Laboratory investigations should be performed when indicated by the patient's medical status, drug therapy, and the nature of the proposed procedure.

Reasonable indications for specific test include:

\begin{tabular}{|c|c|}
\hline Test & Indications \\
\hline Complete blood count & $\begin{array}{l}\text { - Major surgery requiring group } \\
\text { and screen or group and match } \\
\text { - Chronic cardiovascular, } \\
\text { pulmonary, renal, or hepatic } \\
\text { disease } \\
\text { - Malignancy } \\
\text { - Known or suspected anemia, } \\
\text { bleeding diathesis, or myelo- } \\
\text { suppression } \\
\text { - Patient less than } 1 \text { year of age }\end{array}$ \\
\hline Sickle cell screen & $\begin{array}{l}\text { - Genetically predisposed patient } \\
\text { (hemoglobin electrophoresis if } \\
\text { screen is positive) }\end{array}$ \\
\hline $\begin{array}{l}\text { International normalized ratio } \\
\text { (INR), activated partial thrombo- } \\
\text { plastin time }\end{array}$ & $\begin{array}{l}\text { - Anticoagulant therapy } \\
\text { - Bleeding diathesis } \\
\text { - Liver disease }\end{array}$ \\
\hline Electrolytes and creatinine levels & $\begin{array}{l}\text { - Hypertension } \\
\text { - Renal disease } \\
\text { - Diabetes } \\
\text { - Pituitary or adrenal disease } \\
\text { - Digoxin or diuretic therapy or } \\
\text { other drug therapies affecting } \\
\text { electrolytes }\end{array}$ \\
\hline Fasting glucose level & $\begin{array}{l}\text { - Diabetes (should be repeated } \\
\text { on day of surgery) }\end{array}$ \\
\hline
\end{tabular}


continued

\begin{tabular}{ll}
\hline Test & Indications \\
\hline Pregnancy $(\beta-H C G)$ & $\bullet$ Woman who may be pregnant \\
Electro-cardiograph & - Heart disease, diabetes, other risk \\
& factors for cardiac disease \\
& Subarachnoid or intracranial \\
& hemorrhage, cerebrovascular \\
& accident, head trauma \\
Chest radiograph & Cardiac or pulmonary disease \\
& - Malignancy \\
\hline
\end{tabular}

Fasting policies should vary to take into account age and pre-existing medical conditions and should apply to all forms of anesthesia, including monitored anesthesia care. Emergent or urgent procedures should be undertaken after considering the risk of delaying surgery $v s$ the risk of aspiration of gastric contents. The type and amount of food ingested should be considered in determining the duration of fasting. Before elective procedures, the minimum duration of fasting should be

- $8 \mathrm{hr}$ after a meal that includes meat, fried or fatty foods;

- $6 \mathrm{hr}$ after a light meal (such as toast and a clear fluid) or after ingestion of infant formula or non-human milk;

- $4 \mathrm{hr}$ after ingestion of breast milk (no additions are allowed to pumped breast milk);

- $2 \mathrm{hr}$ after clear fluids.

Unless contraindicated, adults and children should be encouraged to drink clear fluids (including water, pulp-free juice and tea or coffee without milk) up to $2 \mathrm{hr}$ before elective surgery.

Premedication, when indicated, should be ordered by the anesthesiologist. Orders should be specific as to dose, time, and route of administration.

Additional regulations governing the conduct of anesthesia may be dictated by provincial legislation or facility by-laws.

\section{The Anesthetic Period}

Before beginning an anesthetic, the anesthesiologist must ensure that

1. An explanation of the planned anesthetic procedure including recognized risks and alternative techniques has been provided and documented;

2. An adequate review of the patient's condition has been performed;

3. All equipment that is expected to be required is available and in working order;

4. A reserve source of oxygen under pressure is available;

5. All drugs and agents that are expected to be required are correctly identified-user-applied drug labels should conform to the CSA Standard CAN/CSAZ264.3-98 (R2005) (Appendix 1);
6. Until a specific connection system is devised for neuraxial use, both sides of all Luer connections are labelled; and

7. The manufacturers' recommendations concerning the use, handling, and disposal of anesthetic equipment and supplies have been considered.

The anesthesiologist's primary responsibility is to the patient receiving care. The anesthesiologist or an anesthesia assistant supervised by the anesthesiologist shall remain with the patient at all times throughout the conduct of all general, major regional, and monitored intravenous anesthetics until the patient is transferred to the care of personnel in an appropriate care unit.

If the attending anesthesiologist leaves the operating room temporarily, he/she must delegate care of the patient to another anesthesiologist, a resident in anesthesia, or an anesthesia assistant. When the attending anesthesiologist delegates care to a resident in anesthesia or an anesthesia assistant, the attending anesthesiologist remains responsible for the anesthetic management of the patient. Before delegating care of the patient to an anesthesia assistant, the anesthesiologist must ensure that the patient's condition is stable and that the anesthesia assistant is familiar with the operative procedure and the operating room environment and equipment. When care is delegated to an anesthesia assistant, the attending anesthesiologist must remain immediately available.

Only under the most exceptional circumstances, e.g., to provide life-saving emergency care to another patient, may an anesthesiologist briefly delegate routine care of a stable patient to a competent person who is not an anesthesia assistant. That person's only responsibility would be to monitor the patient during the anesthesiologist's absence and to keep the anesthesiologist informed until he/she returns. In this situation, the anesthesiologist remains responsible for the care of the patient and must inform the operating team.

Simultaneous administration of general, spinal, epidural, or other major regional anesthesia, or sedation level 4-6 (Ramsay Sedation Scale [RSS], see Appendix 6), by one anesthesiologist for concurrent diagnostic or therapeutic procedures on more than one patient is unacceptable. However, it may be appropriate in specific circumstances for one anesthesiologist to supervise more than one case wherein solely RSS 1-3 sedation is administered, provided that an appropriately trained, qualified, and accredited individual, approved by the health care institution, is in constant attendance with each patient receiving care. However, in an obstetric unit, it is acceptable to supervise more than one patient receiving regional analgesia for labour. Due care must be taken to ensure 
that each patient is adequately observed by a suitably trained person following an established protocol. When an anesthesiologist is providing anesthetic care for an obstetric delivery, a second appropriately trained person should be available to provide neonatal resuscitation.

Simultaneous administration of an anesthetic and performance of a diagnostic or therapeutic procedure by a single physician is unacceptable, except for procedures done with only infiltration of local anesthetic.

\section{Records}

All monitored physiologic variables should be charted at intervals appropriate to the clinical circumstances. Heart rate and blood pressure should be recorded at least every 5 min. Oxygen saturation should be monitored continuously and recorded at frequent intervals. For every patient receiving inhalational, major regional, or monitored intravenous anesthesia, oxygen saturation should be monitored continuously, and end-tidal carbon dioxide concentration should be monitored continuously if the trachea is intubated. Reasons for deviation from these charting guidelines should be documented in the anesthetic record. Monitors, equipment, and techniques, as well as time, dose, and route of all drugs and fluids should be recorded. Intraoperative care should be recorded.

The anesthesia record should include the patient's level of consciousness, heart rate, blood pressure, oxygen saturation, and respiratory rate as first determined in the post-anesthesia care unit (PACU).

\section{Patient Monitoring}

The only indispensable monitor is the presence, at all times, of a physician or an anesthesia assistant who is under the immediate supervision of an anesthesiologist and has appropriate training and experience. Mechanical and electronic monitors are, at best, aids to vigilance. Such devices assist the anesthesiologist to ensure the integrity of the vital organs and, in particular, the adequacy of tissue perfusion and oxygenation.

The health care facility is responsible for the provision and maintenance of monitoring equipment that meets current published equipment standards.

The chief of anesthesia is responsible for advising the health care facility on the procurement of monitoring equipment and for establishing policies for monitoring to help ensure patient safety.
The anesthesiologist is responsible for monitoring the patient receiving care and ensuring that appropriate monitoring equipment is available and working correctly. A pre-anesthetic checklist (Appendix 3 or equivalent) shall be completed prior to initiation of anesthesia.

Monitoring guidelines for standard patient care apply to all patients receiving general anesthesia, regional anesthesia, or intravenous sedation.

Monitoring equipment is classified as one of the following:

- Required: These monitors must be in continuous use throughout the administration of all anesthetics.

- Exclusively available for each patient: These monitors must be available at each anesthetic work station so that they can be applied without any delay.

- Immediately available: These monitors must be available so that they can be applied without undue delay.

The following are required:

- Pulse oximeter;

- Apparatus to measure blood pressure, either directly or non-invasively;

- Electrocardiography;

- Capnography for general anesthesia and sedation (RSS 4-6); and

- Agent-specific anesthetic gas monitor, when inhalation anesthetic agents are used.

The following shall be exclusively available for each patient:

- Apparatus to measure temperature;

- Peripheral nerve stimulator, when neuromuscular blocking drugs are used;

- Stethoscope-either precordial, esophageal, or paratracheal; and

- Appropriate lighting to visualize an exposed portion of the patient.

The following shall be immediately available:

- Spirometer for measurement of tidal volume.

- Manometer to measure endotracheal tube cuff pressure.

It is recognized that brief interruptions of continuous monitoring may be unavoidable. Furthermore, there are certain circumstances in which a monitor may fail and, therefore, continuous vigilance by the anesthesiologist is essential.

Audible and visual alarms for oximetry and capnography should not be indefinitely disabled during the conduct of an anesthetic except during unusual 
circumstances. The variable pitch, pulse tone, and lowthreshold alarm of the pulse oximeter and the capnograph apnea alarm must give an audible and visual warning.

Respiratory monitoring should be considered in non-OR locations (PACU and elsewhere) for sedated patients and those at risk of respiratory depression.

\section{The Post-anesthetic Period}

\section{Recovery Facility}

In any facility providing anesthetic services, a PACU must be available. Administrative policies in accordance with facility by-laws shall be enforced to coordinate medical and nursing care responsibilities.

The department of anesthesia should have overall medical administrative responsibility for the PACU. There should be a policy manual for the PACU, which has been approved by medical, nursing, and administrative authorities.

The anesthesiologist should accompany the patient to the PACU, communicate necessary information, and write appropriate orders. If clinically indicated, supplemental oxygen and appropriate monitoring devices should be applied during transport. Care should not be delegated to the PACU nurse until the anesthesiologist is assured that the patient may be safely observed and cared for by the nursing staff. The anesthesiologist or designated alternate is responsible for providing anesthetic-related care in the PACU. Discharge from the PACU is the responsibility of the anesthesiologist. This responsibility may be delegated in accordance with facility policy.

Supplemental oxygen and suction must be available for every patient in the PACU. Emergency equipment for resuscitation and life support must be available in the PACU. The monitoring used in the PACU should be appropriate to the patient's condition and a full range of monitoring devices should be available. The use of pulse oximetry in the initial phase of recovery is required. Capnography for intubated patients or those deeply sedated is required, with alarm limit settings appropriate to the condition and age of patients. An apnea monitor is recommended for a preterm infant of less than 50 weeks of gestational age.

An accurate record of the immediate recovery period shall be maintained. This must include a record of vital signs together with other aspects of treatment and observation. The recovery record shall form a part of the permanent medical record. Any complications that bear any relation to the anesthetic should be recorded either on the recovery record or on the progress notes on the patient's chart.

In some circumstances, it may be considered acceptable to transfer a patient directly to other care units or to bypass the
PACU if the appropriate level of care is available in another unit in the facility and the suitability of the patient for this transfer is documented on the anesthetic record.

\section{Discharge of Patients After Day Surgery}

Discharge of patients after day surgery must be through the application of a formal care plan approved by the institution and documented in the patient care notes. Specific written instructions should include management of pain, postoperative complications, and routine and emergency follow up. The patient should be advised regarding the additive effects of alcohol and other sedative drugs, the danger of driving or the operation of other hazardous machinery during the postoperative period (most commonly $24 \mathrm{hr}$ postoperatively), and the necessity for attention by a competent adult for the postoperative period (most commonly $24 \mathrm{hr}$ postoperatively).

\section{Guidelines for Obstetric Regional Analgesia}

Anesthesia services to parturients include obstetric analgesia for labour, for both uncomplicated and complicated deliveries, or for operative deliveries. All guidelines regarding provision of anesthesia for other diagnostic or therapeutic procedures also apply to provision of obstetric anesthesia. The guidelines in this section pertain to epidural and spinal analgesia during labour. The term "regional analgesia" includes epidural, spinal, and combined spinal-epidural analgesia.

These guidelines will be reviewed annually by the Section of Obstetric Anesthesia of the Canadian Anesthesiologists' Society and updated as indicated. Each facility may wish to develop additional guidelines or policies for specific situations in which obstetric regional analgesia is provided.

Under the direction of an anesthesiologist, some aspects of monitoring and management of obstetric regional analgesia may be delegated to other health care personnel. Each facility should ensure that these personnel receive the same training, certification, continuing education, and recertification in obstetric regional analgesia.

Initiation of Obstetric Regional Analgesia

1. Before introducing obstetric regional analgesia, the facility should have appropriate monitoring protocols in place. These protocols should outline the types of monitoring required and the frequency of monitoring. In addition, they should clearly state how to manage common problems and emergencies and indicate who to contact if assistance is required. 
2. Obstetric regional analgesia should only be provided by physicians with training, facility privileges, and licence to provide these services. This includes trainees with appropriate supervision.

3. Regional analgesia should only be initiated and maintained in locations where appropriate resuscitation equipment and drugs are immediately available.

4. Informed consent should be obtained and documented in the medical record.

5. Intravenous access must be established before initiating regional analgesia. The intravenous access should be maintained as long as regional analgesia is administered.

6. The anesthesiologist should be immediately available until analgesia is established and the patient's vital signs are stable.

\section{Maintenance of Regional Analgesia During Labour}

Continuous infusions of low-dose (diluted) epidural local anesthetics, with or without other adjuncts, are associated with a very low incidence of significant complications. Consequently, it is not necessary for an anesthesiologist to remain present or immediately available during maintenance of continuous epidural infusion analgesia provided that

- There are appropriate protocols for management of patients receiving patient-controlled epidural analgesia (PCEA).

- The anesthesiologist can be contacted for the purpose of obtaining advice and direction.

A bolus dose of local anesthetic through the epidural catheter or through a catheter or needle presumed to be in the epidural space can cause immediate life-threatening complications. For this reason, an anesthesiologist must be available to intervene appropriately should any complications occur when a bolus dose of local anesthetic is injected through the epidural catheter (except PCEA). The intent of the phrase "available to intervene appropriately" is that individual departments of anesthesiology should establish their own policies regarding the availability of an anesthesiologist to manage any complications of regional analgesia. In developing these policies, each department should consider the possible risk of bolus injection of local anesthetics and the methods of dealing with emergency situations.

\section{Oral Intake During Labour}

Gastric emptying of solids is delayed during labour. Opioid analgesics may further delay gastric emptying. Therefore, parturients should not eat solid foods once they are in established labour. In contrast to solid food, clear liquids are relatively rapidly emptied from the stomach and absorbed in the proximal small bowel, including during labour. Therefore, individual facilities should develop protocols regarding the intake of clear liquids by women in established labour.

\section{Guidelines for Acute Pain Management Using Neuraxial Analgesia}

When neuraxial analgesia is managed by anesthesiologists, the incidence of side effects is no higher than when alternative techniques of pain management are used. Accordingly, when its use is appropriate, neuraxial analgesia should be managed by anesthesiologists.

For the purposes of these guidelines, neuraxial analgesia is defined as intrathecal or epidural administration of opioids and/or local anesthetics for treatment of postoperative pain or other acute pain problems. The purpose of these guidelines is to provide principles of management for anesthesiologists so that neuraxial analgesia is provided in a fashion that maximizes its benefit-risk ratio.

\section{Administrative and Educational Policies}

The department of anesthesia should establish an acute pain service that is responsible for

1. Developing policies and procedures for neuraxial analgesia. Participation of other departments, such as nursing, pharmacy, surgery, and materials management should be sought as needed.

2. Liaison with the surgical departments. Surgeons need to understand the criteria for patient selection, the effects of neuraxial analgesia on the normal postoperative course and on the presentation of postoperative complications, and the implications of other therapies, such as prophylactic anticoagulation, on neuraxial analgesia.

3. Education and certification of nurses. A standardized educational program that includes initial training, certification, and ongoing maintenance of competence should be established for nurses caring for patients receiving neuraxial analgesia. Nursing personnel should understand

- The risk of respiratory depression, including delayed respiratory depression when hydrophilic opioids are used;

- Assessment and management of respiratory depression; 
- Assessment of motor and sensory blockade;

- Assessment and management of hypotension in patients receiving neuraxial analgesia; and

- Signs and symptoms of the rare but catastrophic complications of epidural hematoma or abscess.

\section{Policies for Drug Administration}

Each facility should use a limited number of standard solutions. Preprinted order sheets listing the standard solutions are strongly recommended. Before dispensing any solution that is not standard in the facility, the anesthesiologist should verify the order with nursing and pharmacy personnel and discuss its indications and all concerns relating to its use with the nurses responsible for administering the drug and monitoring the patient.

The risk of errors due to incorrect route of drug injection must be minimized. For continuous infusions or PCEA, the use of unique tamper-proof pumps that are distinct from the pumps used for intravenous fluid or drug administration is strongly recommended. The tubing between neuraxial analgesia infusion pumps and catheters should not have ports that could permit unintentional injection of intravenous drugs.

Preparation of solutions should follow a standardized procedure. All analgesic drug solutions should be labelled with the composition of the solution (opioid, local anesthetic, or both) and its intended route of administration (epidural or intravenous).

\section{Patient Monitoring and Management of Adverse Events}

Patients receiving neuraxial analgesia should be in a room equipped with oxygen and suction. Resuscitation drugs and equipment must be immediately available. Before initiating neuraxial analgesia, intravenous access must be secured, and after discontinuing neuraxial analgesia, intravenous access must be maintained for the expected duration of drug effects.

Epidural catheter dressings should permit examination for catheter movement and daily inspection of the catheter entry site for any signs of infection.

Standardized policies for patient management should be established. The parameters to be assessed, frequency of assessments, documentation, and procedures for management of complications should be specified. Adequate nursing personnel must be available to assess and manage patients receiving neuraxial analgesia. Monitoring should continue after discontinuation of neuraxial analgesia until its effects have dissipated.

An anesthesiologist must be readily available to advise nursing personnel on such issues as dose titration and management of adverse effects. Each facility with an acute pain service should ensure that an anesthesiologist is available to attend directly to patients receiving neuraxial analgesia within an appropriate time depending on the clinical situation. Each facility should also specify procedures for emergent management of any life-threatening complications.

Other drugs, particularly benzodiazepines or parenteral opioids, may cause severe respiratory depression in patients receiving neuraxial analgesia. For this reason, other physicians should not order sedatives or analgesics for any patient receiving neuraxial analgesia. The acute pain service should direct analgesic and sedative therapy until the effects of neuraxial analgesia have dissipated.

Patients with epidural catheters may receive prophylactic low-dose anticoagulant therapy if appropriate precautions are taken.

- To minimize the risk of epidural hematoma, catheter insertion and removal and the timing of anticoagulant administration must be coordinated so that no clinically significant anticoagulant effect is present at these times.

- Use of nonsteroidal anti-inflammatory drugs in patients receiving neuraxial analgesia is appropriate, but concurrent administration of these drugs or other antiplatelet medication and an anticoagulant may increase the risk of epidural hematoma.

- Where neuraxial analgesia is used for prolonged postoperative pain management, every effort should be made to avoid lower extremity motor blockade.

- Nursing staff should be aware of the signs and symptoms of epidural hematoma. Any change in neurologic status or new-onset back pain must be investigated immediately.

If full anticoagulation is indicated in a patient with an epidural catheter, the anesthesiologist should be consulted so that catheter removal and initiation of alternative analgesic management are accomplished before anticoagulation.

\section{Guidelines for the Practice of Anesthesia Outside a Hospital Facility}

The basic principles, training requirements, techniques, equipment, and drugs used for the practice of anesthesia are noted in other sections of these guidelines. The following are guidelines for certain aspects particular to anesthetic practice outside a hospital facility.

\section{Patient Selection}

Patients should be classified as to physical status in a manner similar to that in use by the American Society of Anesthesiologists (Appendix 2). Usually, only patients in 
ASA classifications I and II should be considered for an anesthetic outside a hospital facility. Patients in classification III may be accepted under certain circumstances.

Preoperative Considerations

The patient must have had a recent recorded history, physical examination, and appropriate laboratory investigations. These may be carried out by another physician or anesthesiologist. The duration of fasting before anesthesia should conform to the previously stated guidelines. The patient should be given an information sheet with instructions for pre- and post-anesthetic periods.

\section{Conduct of Anesthesia}

The anesthetic and recovery facilities shall conform to facility standards published by the CSA as defined in other sections. The standards of care and monitoring shall be the same in all anesthetizing locations.

Acknowledgements Contributions to earlier versions of the guidelines from former members of the Committee on Standards to the Practice of Anesthesia are gratefully acknowledged.

Competing interests All authors of this article are members of the Standards Committee of the Canadian Anesthesiologists' Society (CAS). None of the authors has any financial or commercial interest relating to the companies or manufacturers of medical devices referenced either in this article or in the related appendices. Dr. Gregory Dobson is Chair of the Committee on Standards of the CAS.

\section{Appendix 1: Canadian Standards Association- Standards for Equipment}

Available as Electronic Supplementary Material.
Appendix 2: American Society of Anesthesiologists' Classification of Physical Status

Available as Electronic Supplementary Material.

\section{Appendix 3: Pre-Anesthetic Checklist}

Available as Electronic Supplementary Material.

Appendix 4: Guidelines, Standards, and Other Official Statements Available on the Internet

Appendix 4 (available at: http://www.cas.ca/English/ Guidelines) provides a non-exhaustive list of sites with official statements promulgated by other related medical organizations, Canadian and worldwide. This list is provided solely for the convenience of CAS members. The CAS is not responsible for the accuracy, currency, or reliability of the content. The CAS does not offer any guarantee in this regard and is not responsible for the information found through these links, nor does it necessarily endorse the sites or their content. This list includes sites that are updated periodically.

\section{Appendix 5: Position Paper on Anesthesia Assistants: An Official Position Paper of the Canadian Anesthesiologists' Society}

Available as Electronic Supplementary Material.

Appendix 6: Position Paper on Procedural Sedation: An Official Position Paper of the Canadian Anesthesiologists' Society

Available as Electronic Supplementary Material. 


\section{Guide d'exercice de l'anesthésie - Édition révisée 2017}

Résumé Le Guide d'exercice de l'anesthésie, version révisée 2017 (le guide), a été préparé par la Société canadienne des anesthésiologistes (SCA), qui se réserve le droit de décider des termes de sa publication et de sa diffusion. Le guide étant soumis à révision, des versions mises à jour sont publiées chaque année. Le Guide d'exercice de l'anesthésie, version révisée 2017, remplace toutes les versions précédemment publiées de ce document. La SCA incite les anesthésiologistes du Canada à se conformer à son guide d'exercice pour assurer une grande qualité des soins dispensés aux patients, mais elle ne peut garantir les résultats d'une intervention. Chaque anesthésiologiste doit exercer son jugement professionnel pour déterminer la méthode d'intervention la mieux adaptée à l'état du patient. La SCA n'accepte aucune responsabilité de quelque nature que ce soit découlant d'erreurs ou d'omissions ou de l'utilisation des renseignements contenus dans son Guide d'exercice de l'anesthésie.

\section{Préambule}

L'anesthésie est une spécialité dynamique de la médecine. Des progrès constants sont apportés afin d'améliorer les soins anesthésiques offerts aux patients subissant des interventions chirurgicales et obstétricales au Canada. Reflet des progrès accomplis dans le domaine, le présent guide est revu annuellement et révisé de façon périodique.

Les recommandations qu'il comprend sont des lignes directrices de base touchant l'exercice de l'anesthésie dont on se servira pour établir des normes raisonnables et acceptables quant aux soins à donner aux patients. Leur but est de fournir un cadre de soins aux patients qui soit à la fois raisonnable et acceptable, et c'est ainsi qu'elles devraient être interprétées - tout en permettant une certaine flexibilité selon les circonstances. Chaque partie du guide peut être révisée au besoin, si l'évolution de la technologie ou de la pratique le justifie.

\section{Principes de base}

Dans le présent document, le mot anesthésiologiste désigne toute personne qui a un permis d'exercer la médecine avec privilège d'administrer l'anesthésie. L'anesthésie désigne tout procédé qui est appliqué délibérément pour rendre le patient temporairement insensible à la douleur ou à l'environnement externe dans le but d'exécuter une intervention diagnostique ou thérapeutique.

Le présent guide s'adresse à tous les anesthésiologistes du Canada. L'exercice indépendant de l'anesthésie est une spécialité médicale qui, à ce titre, doit être exercée par des médecins ayant une formation appropriée en anesthésie. La seule voie de reconnaissance comme spécialiste en anesthésie au Canada est par le biais du processus de certification du Collège royal des médecins et chirurgiens du Canada. La Société canadienne des anesthésiologistes (SCA) reconnaît que certaines collectivités éloignées n'ont pas une population suffisamment nombreuse pour maintenir un spécialiste certifié en anesthésie en exercice. Afin de dispenser les services d'anesthésie dans ces collectivités, on pourrait devoir recourir à des médecins de famille ayant reçu une formation adéquate. Dans les communautés où le volume clinique est suffisamment important pour justifier l'emploi d'un anesthésiologiste à temps plein, ces services devraient être offerts par un anesthésiologiste ayant complété une surspécialisation. Tous les anesthésiologistes devraient poursuivre leur formation dans la pratique de l'anesthésie, de la prise en charge de la douleur, des soins périopératoires et de la réanimation.

\section{Organisation des services d'anesthésie}

Le département d'anesthésie devrait être, de façon appropriée, organisé, dirigé et intégré aux autres départements de l'organisme ou de l'établissement. Le département d'anesthésie devrait regrouper tous les membres du personnel de l'établissement qui assurent les soins anesthésiques aux patients, aussi bien à des fins chirurgicales et obstétricales que pour des procédures diagnostiques ou thérapeutiques.

Compte tenu de l'ampleur et de la nature des services offerts, le département d'anesthésie devrait pouvoir compter sur le personnel nécessaire pour assurer les services requis par l'établissement.

Le chef du département devrait être un médecin certifié en anesthésie ou encore possédant une formation adéquate en anesthésie. Cette personne devrait être nommée de la même manière que les autres chefs de départements cliniques et devrait faire partie des entités administratives supérieures des soins de santé de l'établissement.

Responsabilités du chef du département d'anesthésie

1. Connaître les directives du présent Guide d'exercice de l'anesthésie de la SCA ainsi que les exigences du Conseil canadien d'agrément des services de santé et celles du Collège des médecins de la province en ce qui a trait à l'anesthésie. 
2. Veiller à ce que, en matière d'exercice de l'anesthésie, des directives écrites soient établies et suivies.

3. Évaluer la compétence et les capacités des médecins qui dispensent les soins anesthésiques, ainsi que celles des autres professionnels de la santé qui assurent les services de soutien - ce qui comprend, sans cependant s'y limiter, les recommandations touchant les privilèges accordés aux médecins qui exercent l'anesthésie et leur révision annuelle.

4. Surveiller systématiquement la qualité des soins anesthésiques à la grandeur de l'établissement de soins de santé. Ceci doit comprendre la révision des dossiers des patients et des vérifications internes du département ou encore un processus d'examen plus détaillé lorsque indiqué.

5. Veiller à constituer et conserver un dossier pour toute procédure d'anesthésie. Ces dossiers doivent permettre de procéder à l'évaluation de l'ensemble des soins anesthésiques dans l'établissement.

6. S'acquitter de toute autre tâche que la direction de l'établissement pourrait lui confier pour assurer des soins anesthésiques sécuritaires.

7. Promouvoir la conformité aux normes applicables de la CSA (Annexe 1) au sein de l'établissement.

8. Coordonner la liaison entre le département d'anesthésiologie et les services de génie biomédical et de gestion de l'information.

\section{Privilèges d'exercice en anesthésie}

Tous les médecins qui demandent le privilège d'exercer l'anesthésie devraient avoir complété avec succès une formation postdoctorale spécialisée en anesthésie. Une telle formation est la norme dans les programmes universitaires approuvés par le Collège royal des médecins et chirurgiens du Canada; les diplômés en médecine en provenance d'autres pays et dont la licence a été approuvée par les organismes provinciaux de réglementation devraient avoir complété une formation équivalente à la norme canadienne. Les médecins de famille pratiquant l'anesthésie doivent avoir complété avec succès un programme de formation postdoctorale spécifique d'une durée d'au moins un an. Certains domaines spécifiques des soins en anesthésie peuvent avoir des problèmes qui leur sont propres. Les privilèges en anesthésie pédiatrique peuvent être définis, dans chaque institution, par le département d'anesthésie, selon la population pédiatrique que l'institution dessert, l'âge de l'enfant et la présence de comorbidités, la formation spécifique du médecin et son expérience en anesthésie pédiatrique, et la complexité de l'intervention en question.
Les médecins qui obtiennent le privilège d'exercer l'anesthésie devraient posséder les connaissances ainsi que les habiletés techniques et non techniques indispensables à la pratique de l'anesthésie.

Ces compétences techniques / fondées sur les connaissances comprennent la capacité de:

- Effectuer une évaluation préanesthésique du patient et décider de la conduite anesthésique appropriée;

- Rendre le patient insensible à la douleur pour la pratique des interventions diagnostiques et thérapeutiques ainsi que pour les interventions chirurgicales et obstétricales;

- Monitorer et soutenir les fonctions vitales des organes en période périopératoire;

- Assurer la prise en charge des soins postanesthésiques immédiats aux patients;

- Pratiquer des manœuvres de réanimation et procurer des soins intensifs lorsque indiqué;

- Procurer le soulagement de la douleur aiguë et chronique.

Les compétences non techniques comprennent:

- La gestion des tâches: planification et préparation, priorisation, prestation et maintien des normes, identification et utilisation des ressources;

- Le travail en équipe: coordination des activités avec les membres de l'équipe, échange des informations, utilisation de l'autorité et de l'affirmation de soi, évaluation des capacités, soutien aux autres, appui de la Liste de contrôle de la sécurité chirurgicale de l'OMS;

- La prise de conscience de la situation: récolte des informations, identification et compréhension, anticipation;

- La prise de décision: identification des options, évaluation des risques et choix des options, réévaluation.

Aptitude à la pratique

La prestation de soins anesthésiques requiert que l'anesthésiologiste possède un niveau élevé d'expertise combiné à un bon jugement, ainsi que la capacité de reconnaître des situations cliniques changeantes et d'y réagir et ce, malgré des circonstances physiques personnelles parfois défavorables. Les départements d'anesthésie doivent être conscients que pour fournir des soins optimaux, les praticiens en anesthésie doivent être en santé. Par conséquent, les départements d'anesthésie ont l'obligation de mettre au point des politiques qui, dans la mesure du possible, garantissent que les praticiens soient en bonne santé et aptes à remplir les obligations liées à leur pratique. 
La santé et l'aptitude au travail peuvent être négativement affectées par divers facteurs, notamment les maladies physiques, les troubles mentaux et la fatigue. Tous ces facteurs altèrent l'aptitude à reconnaître des circonstances cliniques évoluant souvent très rapidement et à y réagir de façon adaptée. De nombreuses études ont démontré que la fatigue altérait le jugement et la performance psychomotrice d'une façon semblable aux drogues ou à l'alcool. Des rythmes circadiens irréguliers, le vieillissement et le manque de sommeil aggravent de tels problèmes; une nonreconnaissance de ces problèmes, causée par la fatigue, peut augmenter la probabilité de commettre des erreurs dans de telles circonstances. Un handicap physique, la maladie et le stress important peuvent avoir des effets néfastes semblables sur la performance.

La responsabilité incombe aux départements d'anesthésie et aux anesthésiologistes en tant qu'individus d'organiser leurs tâches professionnelles de telle sorte que la maladie et la fatigue n'affectent pas régulièrement leurs tâches cliniques. Les listes de garde de chacun doivent permettre un repos adapté entre les quarts de travail et les listes quotidiennes doivent allouer des pauses adaptées afin de respecter les besoins physiologiques, la nutrition et l'aptitude mentale de chaque anesthésiologiste. Les procédures de planification des salles d'opération devraient éviter d'exiger que les anesthésiologistes entreprennent des interventions non urgentes pendant des heures 'défavorables'.

Aucune recommandation spécifique ne peut être faite concernant les quarts de travail et la liste de garde quotidienne, car une telle recommandation ne serait pas adaptée à toutes les situations de travail. Les grands départements disposent de la flexibilité nécessaire à intégrer des quarts de travail courts et des congés personnels, alors que les départements plus petits pourraient ne pas avoir cette liberté. Toutefois, ce domaine important de l'exercice professionnel doit faire l'objet d'une attention et d'une considération constantes.

\section{Résidents}

Les résidents en anesthésie sont des médecins autorisés qui, dans le cadre de leur formation, participent à la prestation des soins anesthésiques tant en salle d'opération qu'à l'extérieur de celle-ci. Toutes les activités des résidents doivent être supervisées par l'anesthésiologiste responsable, tel que requis par le Collège royal des médecins et chirurgiens du Canada, et les organismes de réglementation provinciaux et locaux. Le degré de supervision doit prendre en considération l'état de chaque patient, la nature des soins anesthésiques, ainsi que l'expérience et les capacités du résident (responsabilité professionnelle croissante). À la discrétion de l'anesthésiologiste superviseur, les résidents peuvent fournir une gamme de soins anesthésiques sous un minimum de supervision. Dans tous les cas, l'anesthésiologiste superviseur doit demeurer promptement disponible afin de prodiguer des conseils ou d'assister le résident lors de soins urgents ou de routine. Que la supervision soit directe ou indirecte, une communication étroite entre le résident et l'anesthésiologiste superviseur est essentielle pour des soins sécuritaires aux patients. Chaque département d'anesthésie qui enseigne aux résidents en anesthésie doit avoir des politiques en place concernant leurs activités et leur supervision.

Personnel de soutien

L'établissement de santé doit s'assurer de la disponibilité de personnel de soutien pour remplir un rôle d'assistance auprès de l'anesthésiologiste. Cette assistance doit être disponible en tout temps et en tout lieu où des services d'anesthésie sont offerts. Le personnel de soutien doit posséder les compétences nécessaires à répondre aux besoins spécifiques des domaines de surspécialité de l'anesthésie, ce qui se répercute sur le besoin de compétences spécifiques dans des domaines tels que l'anesthésie spécialisée en pédiatrie.

Il est préférable qu'un établissement dispose d'un « Assistant en anesthésie »(AA) formellement désigné. Ce personnel doit avoir reçu une formation spécifique en assistance en anesthésie. L'étendue des tâches des AA travaillant dans un établissement en particulier doit être approuvée par le département d'anesthésie et les entités administratives compétentes. En outre, les AA, comme les autres professionnels de la santé employés par l'établissement, doivent être protégés par l'assuranceresponsabilité de l'établissement. Les responsabilités et les tâches déléguées aux AA doivent être conformes aux lois et règlements gouvernementaux en vigueur, aux politiques et directives édictées par les organismes de réglementation de la profession, et aux politiques de l'établissement hospitalier.

Un établissement ne disposant pas d'AA en bonne et due forme doit mettre à la disposition de l'anesthésiologiste d'autres employés pour l'assister. Les fonctions qui incombent à ces assistants doivent être clairement définies. L'anesthésiologiste ne doit leur déléguer ou impartir que les tâches pour lesquelles ils ont été autorisés ou accrédités.

\section{Matériel d'anesthésie et lieux convenant à l'anesthésie}

L'anesthésie doit se pratiquer dans un local approprié. Tout le matériel, y compris le matériel d'urgence et les systèmes 
de soutien des fonctions vitales, les médicaments et les autres fournitures, doit être à portée de main.

L'établissement de santé, en consultation avec le département d'anesthésie, est responsable de l'aménagement et de l'entretien des lieux servant aux soins préopératoires, postopératoires et anesthésiques, ainsi que de l'achat, de l'entretien et du traitement après utilisation du matériel et des fournitures servant à l'anesthésie et aux autres fonctions connexes. L'Association canadienne de normalisation (CSA) et d'autres organismes d'élaboration de normes ont publié des normes et des recommandations se rapportant à la conception, la construction et la rénovation des établissements de santé, ainsi que concernant la gestion du risque, les mesures de sécurité de base et les performances essentielles du matériel médical. (Annexe 1)

Il incombe à l'établissement de santé de veiller à l'application des mesures suivantes:

1. Les salles d'opération, d'anesthésie et de soins périopératoires doivent respecter au minimum les exigences minimales de conception et de construction des codes nationaux, provinciaux et locaux concernant la charpente, la plomberie, le chauffage, la ventilation et la climatisation, la protection incendie et l'électricité, au moment de leur construction ou de leur rénovation.

2. Les systèmes d'évacuation des gaz médicaux, de vidange et de récupération des gaz anesthésiques résiduels, les unités terminales, les murs de soutien, les raccordements à basse pression et les régulateurs de pression doivent être conformes aux exigences de la CSA et porter le sceau d'approbation d'une agence de vérification reconnue par la CSA.

3. Les concentrateurs d'oxygène peuvent constituer un substitut acceptable à l'oxygène fourni par un système central en autant qu'ils sont conformes aux normes de la CSA. Lorsque de tels concentrateurs sont installés, il faut savoir:

a. que la fraction d'oxygène inspirée $\left(\mathrm{FiO}_{2}\right)$ dispensée par l'approvisionnement d'oxygène médical de l'établissement peut varier entre 0,93 et 0,99 ;

b. que les analyseurs d'oxygène doivent être calibrés avec de $1^{\prime} \mathrm{O}_{2}$ à $100 \%$ (soit $\mathrm{FiO}_{2}$ 0,99) et à l'air ambiant ou l'équivalent (soit $\mathrm{FiO}_{2}$ 0,21);

c. que l'utilisation de techniques anesthésiques à faible débit (moins de $1 \mathrm{~L}$ de gaz frais total) peut entraîner une accumulation de gaz inerte (argon) et la dilution du protoxyde d'azote et de l'oxygène dans le circuit.

4. L'entreposage, la préparation, l'identification, l'étiquetage, l'élimination et l'utilisation des gaz médicaux, des médicaments et du matériel afférent doivent être conformes à toutes les règles de sécurité.

5. En cas d'anesthésie générale, les systèmes d'anesthésie électroniques doivent répondre à la norme CAN/CSAC22.2 No. 60601-2-13. Une autre méthode de ventilation (par ex. un ballon manuel et un masque de réanimation) doivent être à portée de main à côté de chaque appareil d'anesthésie. Les stations disposeront au moins d'un analyseur d'oxygène, d'un moniteur de la pression des voies aériennes, d'un système d'évacuation des gaz anesthésiques résiduels et d'un puissant appareil de succion trachéale. En cas d'utilisation de vaporisateurs, ceux-ci doivent utiliser un dispositif de remplissage spécifique à chaque agent afin de garantir le remplissage par le bon agent. S'il y a un ventilateur, il sera muni d'une alarme de basse pression ou de déconnexion.

6. Le matériel, les fournitures et l'aide nécessaires à l'exécution sécuritaire de procédures effractives sont disponibles. Des appareils de diagnostic, tels que, entre autres, les neurostimulateurs, les appareils d'échographie, les amplificateurs d'image et les appareils de radiographie, devraient être à la disposition de l'anesthésiologiste au besoin. Des dispositifs d'échographie dédiés doivent être mis à disposition par l'établissement pour l'installation de cathéters veineux centraux et artériels. Le recours à l'échoguidage en temps réel pour le positionnement non urgent d'un cathéter veineux central jugulaire interne est fortement recommandé lorsque la formation et l'expérience avec cette technique existent.

7. Un « chariot de réanimation » comprenant le matériel nécessaire à une réanimation d'urgence, y compris un dispositif de réanimation manuelle, un défibrillateur respectant les Lignes directrices actuelles de la Fondation canadienne des maladies du cœur, les médicaments adaptés et les dispositifs intraveineux, doit être à portée de main. Un « chariot de réanimation pédiatrique » contenant du matériel de réanimation pédiatrique doit être immédiatement disponible dans tout endroit où la sédation, l'anesthésie ou la réanimation d'enfants est réalisée. Une trousse d'urgence pédiatrique comprenant un ruban de Broselow $^{\mathrm{TM}}$ pourrait faciliter la bonne conduite du processus de réanimation.

8. En cas d'utilisation d'agents déclencheurs d'hyperthermie maligne, une trousse d'hyperthermie maligne respectant les lignes directrices de l'Association d'hyperthermie maligne des États-Unis sera disponible immédiatement (Annexe 4).

9. Une « Trousse pour voies aériennes difficiles » sera immédiatement disponibles pour la prise en charge de voies aériennes difficiles ou lors d'un échec 
d'intubation. Les établissements qui prennent soin d'enfants doivent disposer d'équipements pour voies aériennes pédiatriques spécialisés immédiatement disponibles.

10. Les établissements qui prennent soin d'enfants doivent disposer d'équipements pédiatriques spécialisés. Dans tous les endroits où l'on pratique l'anesthésie obstétricale, un endroit spécifique réservé à l'évaluation et à la réanimation du nouveau-né doit être prévu; cet endroit doit être pourvu de sources d'oxygène, de succion et de prises de courant qui lui sont propres, d'une source de chaleur radiante et de matériel nécessaire à la prise en charge des voies aériennes et à la réanimation néonatale.

11. Des dispositifs de protection personnelle, y compris des masques N95, des masques faciaux et des moyens d'élimination des débris dangereux et potentiellement infectieux ainsi que des objets aiguisés, sont à portée de main. Des systèmes d'aspiration de fumée respectant la norme CSA Z305.13-09 dans des environnements chirurgicaux, diagnostiques, thérapeutiques et esthétiques seront installés.

12. Une alimentation en oxygène doit être fournie pour le transport des patients périopératoires. L'utilisation de cylindres de transport d'oxygène qui peuvent émettre une alarme audible lorsque la pression est faible est fortement recommandée.

13. Tout le matériel d'anesthésie et le matériel connexe sera inspecté et entretenu régulièrement par un personnel compétent. L'administration de l'établissement et le département d'anesthésie conserveront les documents qui attestent de l'application des règlements, des inspections et de l'entretien.

Le personnel qui administre l'anesthésie doit s'assurer qu'on ne transmet pas de substances ou d'agents potentiellement infectieux d'un patient à un autre. À cet égard, une attention particulière doit être portée aux seringues, aux tubulures des pompes à perfusion et aux fioles de médicaments multidoses.

Avant d'introduire un appareil en anesthésie, les membres du département d'anesthésie doivent recevoir une formation concernant son utilisation sécuritaire. La participation à ces séances doit être documentée. Ces séances de formation doivent être répétées aussi souvent que nécessaire pour les nouveaux et anciens membres du département.

Recommandations visant à diminuer l'exposition professionnelle aux gaz anesthésiques résiduels:

1. Une ventilation par dilution assurant 20 renouvellements par heure doit être disponible dans toutes les salles d'anesthésie dans lesquelles des gaz anesthésiques volatils ou du $\mathrm{N}_{2} \mathrm{O}$ sont utilisés.
2. La recirculation de l'air vicié ne devrait pas être permise durant les heures d'activité de la salle d'opération et n'est pas recommandée en toute autre période.

3. Partout où un système d'administration de gaz anesthésiques est utilisé, un système d'évacuation doit être mis en place afin de recueillir les gaz anesthésiques qui peuvent s'échapper du circuit d'anesthésie ou du ventilateur.

4. Un programme d'entretien doit être mis en place dans tous les établissements de santé afin de détecter et de réparer toute fuite du système de distribution des gaz anesthésiques et de veiller au bon fonctionnement du système d'évacuation des gaz anesthésiques résiduels.

5. L'établissement de santé sera responsable d'effectuer une surveillance régulière de l'exposition aux gaz anesthésiques résiduels. Le protocole de surveillance devrait inclure les individus et la distribution de l'écoulement de l'air dans les salles évaluées. Lorsque le $\mathrm{N}_{2} \mathrm{O}$ est utilisé en salle d'opération, la surveillance du $\mathrm{N}_{2} \mathrm{O}$ constitue une façon acceptable de vérifier l'efficacité du système d'évacuation des gaz.

\section{La période préanesthésique}

Il incombe au département d'anesthésie de formuler les politiques concernant l'évaluation préanesthésique.

Le principal objet de l'évaluation préanesthésique est d'obtenir les renseignements requis pour planifier la prise en charge anesthésique. En conséquence, tous les aspects des antécédents médico-chirurgicaux du patient, le bilan de l'examen physique et les résultats des analyses de laboratoire qui se rapportent à la prise en charge anesthésique devraient être évalués par un médecin bien informé des pratiques anesthésiques courantes face à la procédure diagnostique ou thérapeutique proposée. L'histoire de cas devrait inclure les problèmes médicaux passés et actuels, la prise de médicaments récente et actuelle, les réactions ou réponses inhabituelles aux médicaments et tous les problèmes et complications associés aux anesthésies administrées antérieurement. Il y a lieu de connaître également les antécédents familiaux de réactions indésirables associées à l'anesthésie et de noter toute information concernant l'anesthésie que le patient juge pertinent de signaler. Il convient enfin d'inscrire au dossier médical de chaque patient le code de classification de l'American Society of Anesthesiologists (Annexe 2).

Dans les cas adaptés, la disponibilité d'un « Plan de soins avancés » (accord de représentation, recommandation avancée, 'testament biologique', directive 'ne pas réanimer', etc.) doit être vérifiée et son applicabilité à l'intervention 
proposée doit être déterminée et documentée au dossier d'évaluation anesthésique.

Le chirurgien peut solliciter une consultation avec un anesthésiologiste. Toutes les consultations médicales indiquées doivent être obtenues.

Le bilan ou la consultation anesthésique préopératoire peut avoir lieu en clinique externe avant l'admission pour l'opération. Les indications concernant l'évaluation préalable à l'admission comprennent l'existence de problèmes médicaux importants (comorbidités), la nature de la procédure diagnostique ou thérapeutique proposée et la demande du patient. La présence d'un parent / tuteur légal est nécessaire si le patient est un enfant ou n'est pas apte à fournir un consentement éclairé. Il faut informer tous les patients que s'ils souhaitent s'entretenir, avant l'admission à l'établissement, de leur anesthésie avec un anesthésiologiste, des dispositions peuvent être prises en ce sens. La clinique d'évaluation préopératoire devrait également permettre au personnel infirmier et aux autres membres du personnel de santé d'évaluer le patient. L'anesthésiologiste en charge du patient est responsable de l'évaluation finale durant la période préopératoire immédiate.

Les tests de laboratoire ne devraient pas être réalisés sur une base régulière mais uniquement lorsque les résultats modifieront la prise en charge périopératoire. Les analyses de laboratoire devraient être réalisées lorsque l'état du patient, le traitement médicamenteux et la nature de l'intervention proposée les justifient.

Voici quelques indications raisonnables pour réaliser des tests spécifiques:

\begin{tabular}{|c|c|}
\hline Test & Indications \\
\hline Hémogramme complet & $\begin{array}{l}\text { - Chirurgie lourde exigeant la } \\
\text { détermination du groupe } \\
\text { sanguin et un test de dépistage } \\
\text { d'anticorps ou un test de } \\
\text { compatibilité } \\
\text { - Affection cardiovasculaire, } \\
\text { pulmonaire, rénale ou hépatique } \\
\text { chronique } \\
\text { - Tumeur maligne } \\
\text { - Anémie connue ou soupçonnée, } \\
\text { diathèse hémorragique ou } \\
\text { aplasie médullaire } \\
\text { - Patient de moins d'un an }\end{array}$ \\
\hline Test de falciformation & $\begin{array}{l}\text { - Patients ayant une prédisposition } \\
\text { génétique (électrophorèse de } \\
\text { l'hémoglobine si le test est } \\
\text { positif) }\end{array}$ \\
\hline $\begin{array}{l}\text { Rapport international normalisé } \\
\text { (INR), temps de céphaline } \\
\text { activée }\end{array}$ & $\begin{array}{l}\text { - Traitement aux anticoagulants } \\
\text { - Diathèse hémorragique } \\
\text { - Maladie hépatique }\end{array}$ \\
\hline
\end{tabular}

continued

\begin{tabular}{|c|c|}
\hline Test & Indications \\
\hline Électrolytes et créatinine & $\begin{array}{l}\text { - Hypertension } \\
\text { - Néphropathie } \\
\text { - Diabète } \\
\text { - Maladie hypophysaire ou } \\
\text { surrénalienne } \\
\text { - Traitement avec diurétiques ou } \\
\text { digoxine, ou autres } \\
\text { médicaments affectant les } \\
\text { électrolytes }\end{array}$ \\
\hline Glycémie à jeun & $\begin{array}{l}\text { - Diabète (doit être répété le jour } \\
\text { de l'intervention chirurgicale) }\end{array}$ \\
\hline Grossesse ( $\beta$-HCG) & $\begin{array}{l}\text { - Toute femme susceptible d'être } \\
\text { enceinte }\end{array}$ \\
\hline Électrocardiogramme & $\begin{array}{l}\text { - Maladie cardiaque, diabète, } \\
\text { autres facteurs de risque de } \\
\text { maladie cardiaque } \\
\text { - Hémorragie sous-arachnoïdienne } \\
\text { ou intracrânienne, accident } \\
\text { vasculaire cérébral, traumatisme } \\
\text { crânien }\end{array}$ \\
\hline Radiographie du thorax & $\begin{array}{l}\text { - Cardiopathie ou affection } \\
\text { pulmonaire } \\
\text { - Tumeur maligne }\end{array}$ \\
\hline
\end{tabular}

Les règles concernant le jeûne devraient varier en fonction de l'âge du patient et de ses antécédents médicaux et s'appliquer à toutes les formes d'anesthésie, y compris les soins anesthésiques monitorés. Les interventions très urgentes ou urgentes doivent être réalisées après avoir examiné les risques qu'entraînerait leur report comparativement au risque d'aspiration du contenu de l'estomac. Le type et la quantité de nourriture absorbée doivent être pris en considération pour déterminer la durée du jeûne. La durée minimale du jeûne précédant une chirurgie non urgente (élective) doit être:

- de huit heures après un repas composé de viande ou d'aliments frits ou gras;

- de six heures après un repas léger (pain grillé et liquides clairs, par exemple) ou après l'ingestion de préparations pour nourrissons ou de lait non humain;

- de quatre heures après l'ingestion de lait maternel (aucun ajout n'est permis au lait maternel tiré);

- de deux heures après l'ingestion de liquides clairs.

Sauf contre-indication, il convient d'encourager adultes et enfants à boire des liquides clairs (eau, jus sans pulpe et thé ou café sans lait) jusqu'à deux heures avant une chirurgie non urgente.

Il incombe à l'anesthésiologiste de prescrire la prémédication lorsque celle-ci est indiquée. L'ordonnance doit en préciser la dose, le moment et la voie d'administration. 
L'administration de l'anesthésie peut aussi faire l'objet d'autres directives prescrites par les lois provinciales ou la réglementation de l'établissement.

\section{La période anesthésique}

Avant le début de l'anesthésie, l'anesthésiologiste doit vérifier les points suivants:

1. la procédure anesthésique prévue a été expliquée au patient, y compris les risques reconnus et les techniques alternatives, et on a documenté cette explication;

2. on a fait le point sur l'état du patient;

3. tout l'équipement qu'on prévoit nécessaire est accessible et en bon état de fonctionnement;

4. on a accès à une source de réserve d'oxygène sous pression;

5. tous les médicaments et agents qu'on prévoit nécessaires sont correctement identifiés. Les étiquettes de médicament apposées par l'usager doivent être conformes à la norme CAN/CSAZ264.3-98 (R2005) (Annexe 1);

6. jusqu'à ce qu'un système de connexion spécifique soit créé pour utilisation neuraxiale, les deux côtés de toutes les connexions de type Luer devraient être étiquetés;

7. on a tenu compte des indications du fabricant quant à l'utilisation, à la manipulation et à la disposition de l'équipement et du matériel d'anesthésie.

L'anesthésiologiste est avant tout responsable du patient qu'il a sous ses soins. L'anesthésiologiste ou un assistant en anesthésie supervisé par l'anesthésiologiste doit demeurer constamment aux côtés du patient pour toute la durée d'une anesthésie générale, loco-régionale majeure et intraveineuse monitorée, jusqu'à ce que le patient ait été confié aux soins du personnel de l'unité de soins compétente.

$\mathrm{Si}$ l'anesthésiologiste traitant doit quitter temporairement la salle d'opération, il doit confier les soins du patient à un autre anesthésiologiste, à un résident en anesthésie ou à un assistant en anesthésie. Dans les cas où il délègue les soins à un résident ou à un assistant en anesthésie, l'anesthésiologiste traitant demeure responsable de la prise en charge anesthésique du patient. Avant de déléguer les soins du patient à un assistant en anesthésie, l'anesthésiologiste doit s'assurer que ce dernier est familier avec le type d'intervention chirurgicale, l'environnement et le matériel de la salle d'opération, et que l'état du patient est stable. Lorsque les soins sont délégués à un assistant en anesthésie, l'anesthésiologiste traitant doit demeurer immédiatement disponible.

Ce n'est qu'en de très rares exceptions, pour se porter par exemple au secours d'un autre patient dont la vie est en danger, qu'un anesthésiologiste pourra brièvement confier les soins courants d'un patient dont l'état est stable à une personne compétente qui n'est pas un assistant en anesthésie, la responsabilité de cette dernière devant se limiter à surveiller le patient en son absence et à tenir l'anesthésiologiste informé jusqu'à son retour. Dans de telles circonstances, l'anesthésiologiste demeure responsable des soins prodigués au patient et se doit de tenir l'équipe chirurgicale au courant.

L'administration simultanée d'une anesthésie générale, rachidienne, péridurale ou autre anesthésie loco-régionale majeure ou d'une sédation de niveau 4-6 sur l'échelle de sédation de Ramsay (RSS - Annexe 6) par un anesthésiologiste pour des interventions diagnostiques ou thérapeutiques pratiquées sur plus d'un patient à la fois est inacceptable. Toutefois, il peut être admis, dans des circonstances particulières, qu'un anesthésiologiste supervise plus d'un cas dans lesquels seulement une sédation de 1-3 sur l'échelle de Ramsay est administrée, à condition qu'un individu ayant reçu une formation adéquate, qualifié, accrédité et approuvé par l'établissement de santé, soit constamment présent auprès de chaque patient recevant des soins. Il sera par contre admis, dans un service d'obstétrique, de surveiller simultanément plus d'une patiente à laquelle est administrée une analgésie locorégionale pendant le travail. Chaque parturiente devra cependant être surveillée adéquatement par une personne compétente, suivant un protocole établi. Lorsque l'anesthésiologiste dispense des soins anesthésiques en vue d'un accouchement, une deuxième personne dûment formée doit se tenir prête à intervenir pour pratiquer au besoin la réanimation néonatale.

L'administration d'une anesthésie simultanément à la réalisation d'une procédure diagnostique ou thérapeutique par un seul médecin est inacceptable, exception faite des interventions réalisées par seule infiltration d'anesthésiques locaux.

\section{Dossiers}

Toutes les variables physiologiques monitorées doivent être enregistrées à intervalles réguliers, en fonction des circonstances cliniques. La fréquence cardiaque et la tension artérielle doivent être enregistrées au moins à toutes les cinq minutes. La saturation en oxygène doit être monitorée constamment et enregistrée à intervalles fréquents. Il faut monitorer la saturation en oxygène de tout patient recevant une anesthésie par inhalation, une anesthésie régionale majeure ou une anesthésie 
intraveineuse monitorée et de plus, si la trachée est intubée, il faut monitorer continuellement la $\mathrm{PCO}_{2}$ télé-expiratoire. On doit documenter au dossier anesthésique toute raison pour laquelle on déroge à cette directive pour la tenue du dossier. Les types de moniteurs, l'équipement et les techniques utilisés doivent être notés aussi bien que l'heure, la dose et la voie d'administration de tout médicament et de tout liquide. L'ensemble des soins peropératoires devrait être noté.

Le dossier anesthésique doit aussi comprendre le niveau de conscience du patient, sa fréquence cardiaque, sa tension artérielle, sa saturation en oxygène et sa fréquence respiratoire à l'arrivée en salle de réveil.

\section{Monitorage du patient}

Le seul moniteur indispensable est la présence, à tous les instants, d'un médecin ou d'un assistant en anesthésie placé sous la supervision immédiate d'un anesthésiologiste et détenant la formation et l'expérience appropriées. Les moniteurs mécaniques et électroniques ne sont, au mieux, que des aides à la vigilance. Ces appareils aident l'anesthésiologiste à s'assurer de l'intégrité des organes vitaux et notamment de la perfusion et de l'oxygénation satisfaisantes des tissus.

Il incombe à l'établissement de fournir et d'entretenir un équipement de monitorage qui répond aux normes en vigueur.

Il incombe au chef du département d'anesthésie de conseiller l'établissement au sujet de l'acquisition de l'équipement de monitorage et d'établir les normes de monitorage qui aideront à assurer la sécurité du patient.

L'anesthésiologiste est responsable du monitorage du patient qui est sous ses soins et il doit s'assurer que l'équipement de monitorage approprié soit disponible et fonctionne correctement. Une feuille de vérification préanesthésique doit être remplie avant d'initier une anesthésie (Annexe 3 ou équivalent).

Les directives de monitorage pour les soins routiniers s'appliquent à tous les patients recevant une anesthésie générale, une anesthésie régionale ou une sédation intraveineuse.

On peut classer l'équipement de monitorage comme suit:

- Requis: ces moniteurs doivent être utilisés sans interruption pendant toute la durée de l'administration de toute anesthésie.

- Accessible en exclusivité pour chaque patient: ces moniteurs doivent être accessibles à chaque poste de travail d'anesthésie, de sorte qu'on puisse y avoir recours sans délai.
- Immédiatement disponible: ces moniteurs doivent être accessibles de sorte qu'on puisse y avoir recours sans délai indu.

\section{Les équipements requis sont:}

- un saturomètre;

- un appareil permettant de mesurer la tension artérielle, directement ou sans effraction;

- un électrocardiographe;

- un capnographe, pour l'anesthésie générale et la sédation (RSS 4-6);

- un moniteur de gaz anesthésiques capable d'identifier et de mesurer chaque agent, lorsque des gaz anesthésiques sont utilisés.

Les équipements suivants doivent être accessibles en exclusivité:

- un appareil pour mesurer la température;

- un stimulateur des nerfs périphériques, lorsqu'on a recours à des bloqueurs neuromusculaires;

- un stéthoscope précordial, œsophagien ou paratrachéal;

- un éclairage suffisant pour bien voir une partie exposée du patient.

Les équipements suivants devront être immédiatement disponibles:

- un spiromètre pour mesurer le volume respiratoire.

- un manomètre pour mesurer la pression du ballonnet dutube endotrachéal.

Il est inévitable que le monitorage continu soit parfois brièvement interrompu. De plus, la possibilité existe qu'un moniteur fasse défaut, ce qui rend essentielle la vigilance soutenue de l'anesthésiologiste.

Les alarmes audibles et visuelles du saturomètre et du capnographe ne devraient pas être désactivées indéfiniment durant le déroulement d'une anesthésie, sauf en cas de circonstances inhabituelles. Le son à tonalité variable des pulsations cardiaques et l'alarme de seuil inférieur du saturomètre et du capnographe doivent émettre un signal audible et visible.

Le monitorage de la respiration doit être envisagé en dehors de la salle d'opération (en salle de réveil et ailleurs) pour les patients sous sédation et pour ceux présentant un risque de dépression respiratoire.

\section{La période postanesthésique}

La salle de réveil

Tous les établissements qui offrent des services d'anesthésie doivent avoir une salle de réveil. Des 
politiques administratives conformes aux règlements de l'établissement devront être appliquées de façon à coordonner les responsabilités des soins médicaux et infirmiers.

L'ensemble de la responsabilité administrative médicale pour la salle de réveil devrait revenir au département d'anesthésie. Il devrait exister un manuel des politiques de la salle de réveil, préalablement approuvé par les autorités médicales, infirmières et administratives de l'établissement.

L'anesthésiologiste devrait accompagner le patient à la salle de réveil, transmettre les renseignements nécessaires et rédiger les ordonnances appropriées. Un supplément d'oxygène et des appareils de monitorage appropriés doivent être utilisés durant le transport si indiqué cliniquement. Le soin du patient ne devrait pas être confié à l'infirmière de la salle de réveil tant que l'anesthésiologiste n'est pas assuré que le personnel infirmier pourra observer et traiter adéquatement le patient. L'anesthésiologiste lui-même ou un anesthésiologiste remplaçant désigné est responsable des soins postanesthésiques à la salle de réveil. Le congé de la salle de réveil est sous la responsabilité de l'anesthésiologiste. Cette responsabilité peut être déléguée, en accord avec les politiques de l'établissement.

Une source d'oxygène et une succion doivent être disponibles pour chaque patient à la salle de réveil. L'équipement d'urgence nécessaire pour procéder à la réanimation et au support vital doit se trouver dans la salle de réveil. Le monitorage utilisé à la salle de réveil doit être adapté à l'état du patient et un assortiment complet de moniteurs doit être disponible. L'utilisation d'un saturomètre durant la phase initiale du réveil est requise. La capnographie est requise chez les patients intubés et les patients sous sédation profonde, avec des paramètres d'alarme adaptés selon l'état et l'âge du patient. Un moniteur d'apnée est recommandé chez les nourrissons nés avant terme de moins de 50 semaines d'âge gestationnel.

On doit tenir un dossier détaillé de la période immédiate du réveil. Celui-ci doit contenir un enregistrement des signes vitaux ainsi que les autres aspects du traitement et de l'observation. Cette feuille d'observation fait partie du dossier médical permanent. Toute complication qui peut avoir un lien avec l'anesthésie doit être notée sur la feuille de la salle de réveil ou encore dans les notes d'évolution du dossier du patient.

Dans certaines situations, il peut être acceptable de transférer un patient directement à d'autres services de soins ou de passer outre la salle de réveil si un niveau de soins adapté est disponible dans un autre service de l'établissement, et le fait que le patient est jugé apte à ce transfert est documenté dans le dossier anesthésique.
Congé des patients après chirurgie d'un jour

Le congé des patients après une chirurgie ambulatoire doit se faire par le biais de l'application d'un plan formel de soins approuvé par l'institution et documenté dans les notes de soins prodigués aux patients. La prise en charge de la douleur, les complications postopératoires ainsi que le suivi de routine et d'urgence doivent tous faire l'objet d'instructions écrites spécifiques. Le patient doit être averti au sujet des synergies additives qu'il existe entre l'alcool et d'autres sédatifs, au sujet du danger de conduire ou d'utiliser des machines dangereuses dans la période postopératoire (dans la plupart des cas durant les 24 heures suivant l'opération), et au sujet de la nécessité d'attention de la part d'un adulte compétent dans la période postopératoire (dans la plupart des cas durant les 24 heures suivant l'opération).

\section{Lignes directrices pour l'analgésie régionale en obstétrique}

Les services d'anesthésie aux parturientes comprennent l'analgésie obstétricale pour le travail, pour l'accouchement avec ou sans complication, et pour césarienne. Toutes les directives visant l'anesthésie administrée pour toute autre intervention diagnostique ou thérapeutique s'appliquent également à l'anesthésie obstétricale. Les directives de la présente section portent sur l'anesthésie péridurale et la rachianesthésie pendant le travail. L'expression "analgésie régionale" désigne l'analgésie péridurale, la rachianesthésie et la combinaison des deux. La Section d'anesthésie obstétricale reverra ces directives à tous les ans et les mettra à jour au besoin. Les établissements offrant des services d'analgésie régionale en obstétrique voudront peut-être élaborer leurs propres directives ou règlements, complémentaires aux présentes et applicables à des situations particulières.

Sous la direction d'un anesthésiologiste, certains aspects du monitorage et de l'administration de l'analgésie régionale en obstétrique peuvent être délégués à d'autres membres du personnel de santé. Chaque établissement doit s'assurer que ces personnes reçoivent les mêmes formation, certification, formation continue et recertification en analgésie régionale en obstétrique.

Éléments requis pour l'utilisation de l'analgésie régionale en obstétrique

1. Avant d'offrir l'analgésie régionale en obstétrique, l'établissement doit disposer de protocoles de monitorage appropriés. Ces protocoles préciseront les 
types de monitorage requis et leur fréquence. En outre, ils préciseront clairement la manière de gérer les problèmes et les urgences communément rencontrés et à qui faire appel en cas de besoin d'assistance.

2. Seuls les médecins ayant la formation et la certification voulues ainsi que les privilèges hospitaliers requis peuvent pratiquer l'analgésie régionale en obstétrique. Cela vaut aussi pour les stagiaires travaillant sous supervision.

3. L'analgésie régionale ne doit être amorcée et maintenue qu'aux endroits qui disposent du matériel et des médicaments de réanimation appropriés et immédiatement accessibles.

4. Le consentement éclairé doit être obtenu et noté dans le dossier médical.

5. Un accès intraveineux doit être établi avant d'amorcer l'analgésie régionale et maintenu pendant toute la durée de cette analgésie.

6. L'anesthésiologiste doit être immédiatement disponible jusqu'à ce que l'analgésie soit établie et que les signes vitaux de la patiente se soient stabilisés.

Maintien de l'analgésie régionale pendant le travail

L'administration continue, sous perfusion, d'une faible dose d'anesthésiques locaux (dilués) par voie péridurale, avec ou sans ajouts, est associée à une incidence très faible de complications significatives. Par conséquent, il n'est pas nécessaire que l'anesthésiologiste reste présent ou soit immédiatement disponible pendant le maintien de la perfusion péridurale à condition que:

- l'on dispose de protocoles de soins appropriés pour les patientes recevant une analgésie péridurale;

- l'on puisse joindre l'anesthésiologiste pour obtenir conseils et instructions.

Un bolus d'anesthésiques locaux administré par cathéter péridural, ou par cathéter ou aiguille présumé être dans l'espace péridural, peut entraîner des complications immédiates mettant la vie en danger. C'est pourquoi, lorsqu'un bolus d'anesthésiques locaux est administré par cathéter péridural (sauf pour l'APCP), un anesthésiologiste doit être disponible pour intervenir comme il se doit en cas de complications L'expression "disponible pour intervenir comme il se doit" est employée intentionnellement pour indiquer que les départements d'anesthésie devraient établir individuellement leurs propres politiques concernant la disponibilité d'un anesthésiologiste pour gérer les complications de l'analgésie régionale. Chaque département devrait considérer, au moment d'élaborer ses politiques, le risque possible que présente l'injection d'un bolus d'anesthésiques locaux et les méthodes d'intervention en cas d'urgence.
Absorption orale pendant le travail

La vidange gastrique des aliments solides est retardée durant le travail. Les analgésiques opioïdes peuvent la retarder davantage. Par conséquent, les parturientes ne devraient pas absorber d'aliments solides une fois le travail actif débuté. Comparativement aux aliments solides, les liquides clairs sont rapidement évacués de l'estomac et absorbés par l'intestin grêle proximal même pendant le travail. Par conséquent, les hôpitaux devraient élaborer leur propre protocole concernant l'absorption de liquides clairs par les femmes en travail actif.

\section{Lignes directrices pour la prise en charge de la douleur aiguë à l'aide de l'analgésie neuraxiale}

Lorsque l'analgésie neuraxiale est prise en charge par des anesthésiologistes, l'incidence des effets secondaires n'est pas plus élevée que lorsque des techniques alternatives de contrôle de la douleur sont utilisées. En conséquence, lorsque son utilisation est indiquée, l'analgésie neuraxiale devrait être prise en charge par les anesthésiologistes.

Aux fins de ce guide, l'analgésie neuraxiale se définit comme étant l'administration intrathécale ou péridurale d'opioïdes et/ou d'anesthésiques locaux en vue du traitement de la douleur postopératoire ou d'autres problèmes de douleur aiguë. L'objet de ce guide est de fournir aux anesthésiologistes des principes de prise en charge afin que l'analgésie neuraxiale soit pratiquée de manière à en maximiser les avantages et minimiser les risques.

\section{Politiques administratives et éducatives}

Le département d'anesthésie devrait mettre sur pied un service de traitement de la douleur aiguë responsable des activités suivantes:

1. Élaboration des politiques et procédures en matière d'analgésie neuraxiale. La collaboration d'autres départements dont ceux des soins infirmiers, de pharmacie, de chirurgie et de gestion du matériel doit être sollicitée au besoin.

2. Liaison avec les départements de chirurgie. Les chirurgiens doivent comprendre les critères de sélection des patients, les effets de l'analgésie neuraxiale sur l'évolution postopératoire normale et sur le mode de présentation des complications postopératoires, ainsi que les implications d'autres thérapeutiques (par exemple l'anticoagulothérapie prophylactique) sur l'analgésie neuraxiale.

3. Éducation et certification des infirmiers et infirmières. Un programme éducatif standard devrait 
être établi pour la formation initiale, la certification et le maintien de la compétence des infirmiers et infirmières qui dispensent des soins aux patients auxquels est administrée une analgésie neuraxiale. Le personnel infirmier doit connaître:

- le risque de dépression respiratoire, y compris la dépression respiratoire tardive lors de l'utilisation d'opioïdes hydrophiles;

- l'évaluation et le traitement de la dépression respiratoire;

- l'évaluation d'un bloc sensoriel et moteur;

- l'évaluation et le traitement de l'hypotension chez le patient recevant une analgésie neuraxiale;

- les signes et symptômes des complications rares mais catastrophiques que sont l'hématome ou l'abcès péridural.

Politiques en matière d'administration de médicaments

Chaque établissement devrait employer un nombre limité de solutions standard. Il est vivement recommandé d'utiliser des formules d'ordonnance préimprimées énumérant lesdites solutions standard. Avant de faire préparer toute autre solution non standard dans son établissement, l'anesthésiologiste devrait vérifier l'ordonnance avec le personnel infirmier et celui de la pharmacie et en discuter les indications et toutes les précautions relatives à son emploi avec les infirmiers et infirmières responsables de l'administration du médicament et du monitorage du patient.

Le risque d'erreurs attribuables à une voie impropre d'injection du médicament doit être minimisé. Pour des perfusions continues ou une analgésie péridurale sous le contrôle du patient (APCP), l'emploi de pompes inviolables distinctes de celles qui sont utilisées pour l'administration de solutés ou de médicaments par voie intraveineuse est vivement recommandé. La tubulure entre les pompes de perfusion de l'analgésie neuraxiale et les cathéters ne devrait comporter aucun orifice susceptible de permettre une injection non intentionnelle de médicaments intraveineux.

La préparation des solutions devrait suivre une procédure standard. Toutes les solutions analgésiques devraient porter une étiquette indiquant la composition de la solution (opioïde, anesthésique local ou les deux) ainsi que la voie d'administration appropriée (péridurale ou intraveineuse).

Monitorage des patients et prise en charge des

événements indésirables

Les patients auxquels est administrée une analgésie neuraxiale devraient être placés dans une chambre équipée d'oxygène et de succion. Des médicaments et un équipement de réanimation doivent être accessibles immédiatement. L'accès intraveineux doit être établi avant d'amorcer l'analgésie neuraxiale et maintenu pendant toute la durée prévue des effets médicamenteux après cessation de l'analgésie neuraxiale.

Le pansement qui maintient en place le cathéter péridural doit permettre l'examen du cathéter pour détecter tout mouvement et permettre l'inspection quotidienne du point d'entrée afin de déceler tout signe d'infection.

L'adoption de politiques standard au chapitre de la prise en charge du patient est préconisée. Les paramètres qu'il convient d'évaluer, la fréquence des évaluations, la documentation et les procédures de prise en charge des complications doivent être précisés. Un personnel de soins infirmiers en nombre suffisant doit être présent pour évaluer et contrôler l'état des patients qui reçoivent une analgésie neuraxiale. Le monitorage doit se poursuivre après cessation de l'analgésie neuraxiale jusqu'à ce que ses effets se soient dissipés.

Un anesthésiologiste doit être immédiatement disponible afin de conseiller le personnel infirmier sur des aspects tels que le titrage de la dose et la prise en charge des réactions adverses. Chaque centre hospitalier doté d'un service de douleur aiguë doit veiller à ce qu'un anesthésiologiste soit disponible pour s'occuper directement des patients recevant une analgésie neuraxiale et ce dans un délai approprié à la situation clinique. Chaque centre hospitalier devrait également déterminer les procédures en vue d'une prise en charge urgente de toutes les complications menaçant le pronostic vital.

D'autres médicaments, notamment les benzodiazépines ou les opiö̈des parentéraux, peuvent causer une dépression respiratoire grave chez les patients recevant une analgésie neuraxiale. Pour cette raison, les autres médecins ne devraient pas prescrire de sédatifs ou d'analgésiques chez tout patient recevant une analgésie neuraxiale. Le service de traitement de la douleur aiguë devrait demeurer en charge de la thérapeutique analgésique et sédative jusqu'à cessation des effets de l'analgésie neuraxiale.

Les patients porteurs d'un cathéter péridural peuvent recevoir un traitement prophylactique par des anticoagulants administrés à faible dose, sous réserve des précautions suivantes:

- Afin de minimiser le risque d'un hématome péridural, l'horaire de l'administration de l'anticoagulant doit être coordonné à l'installation et au retrait du cathéter de telle sorte qu'aucun effet anticoagulant clinique significatif ne soit présent à ces moments.

- L'emploi de médicaments anti-inflammatoires non stérö̈diens chez des patients auxquels est administrée une analgésie neuraxiale s'avère approprié, mais l'administration concomitante de ces médicaments ou 
d'autres antiagrégants plaquettaires et d'un anticoagulant peut accroître le risque d'un hématome péridural.

- Le blocage moteur des membres inférieurs devrait être évité autant que possible chez les patients recevant une analgésie neuraxiale pour le contrôle prolongé de la douleur postopératoire.

- Le personnel infirmier doit connaître les signes et les symptômes d'un hématome péridural. La cause de toute altération de l'état neurologique ou apparition soudaine d'une douleur dorsale doit être recherchée immédiatement.

Si une anticoagulothérapie complète est indiquée chez un patient porteur d'un cathéter péridural, l'anesthésiologiste devrait être consulté afin que le retrait du cathéter et l'amorce d'un traitement analgésique substitutif puissent être effectués avant le début de l'anticoagulothérapie.

\section{Lignes directrices pour l'exercice de l'anesthésie hors du milieu hospitalier}

On a exposé dans les pages précédentes les directives quant aux principes fondamentaux, aux exigences de formation, aux techniques anesthésiques, à l'équipement et aux médicaments utilisés dans l'exercice de l'anesthésie. Suivent maintenant des directives concernant certains aspects particuliers à l'exercice de l'anesthésie à l'extérieur d'un établissement.

\section{Sélection des patients}

On devrait s'inspirer du code de classification de l'American Society of Anesthesiologists (voir Annexe 2) pour faire l'évaluation des patients, et ne retenir, pour l'anesthésie hors du milieu hospitalier, que ceux des classes I et II. On ne devrait accepter ceux de la classe III qu'à certaines conditions.

\section{Considérations préopératoires}

Une histoire de cas et un examen physique récents devraient paraître au dossier, ainsi que les résultats des examens de laboratoire appropriés. Ceci peut être fait par un autre médecin ou par un autre anesthésiologiste. La durée du jeûne préanesthésique devrait respecter les directives émises précédemment. Le patient devrait recevoir un feuillet d'information contenant toutes les directives relatives aux périodes pré- et postanesthésiques.

Conduite de l'anesthésie

Les installations des salles d'anesthésie et de réveil doivent répondre aux normes hospitalières de l'Association canadienne de normalisation telles qu'indiquées dans les autres parties du présent guide. Les normes de soins et de monitorage doivent être les mêmes, quel que soit l'endroit où est administrée l'anesthésie.

Remerciements Nous tenons à remercier les anciens membres du comité des Normes de pratique de l'anesthésie qui ont apporté leurs contributions à des versions antérieures de ce guide.

Conflits d'intérêt Tous les auteurs de cet article font partie du comité des Normes de pratique de l'anesthésie de la Société canadienne des anesthésiologistes (SCA). Aucun des auteurs n'a un quelconque intérêt financier ou commercial lié aux sociétés ou fabricants d'appareils médicaux dont il est fait mention dans cet article ou dans les annexes associées. Dr Gregory Dobson est président du comité des Normes de pratique de la SCA.

\section{Annexe 1: Normes de l'Association canadienne de normalisation (CSA) au sujet de l'équipement}

(disponible en matériel électronique supplémentaire Annexe 1)

Annexe 2: Classification de l'état de santé des patients, selon l'American Society of Anesthesiologists

(disponible en matériel électronique supplémentaire Annexe 2)

\section{Annexe 3: Liste de vérification préanesthésique}

(disponible en matériel électronique supplémentaire Annexe 3)

\section{Annexe 4: Lignes directrices, normes et autres énoncés officiels disponibles sur l'internet}

L'annexe 4 offre une liste non exhaustive de sites contenant des déclarations officielles promulguées par d'autres associations médicales, au Canada et ailleurs dans le monde. Cette liste est fournie aux membres de la SCA uniquement pour des raisons pratiques. La SCA n'est pas responsable de l'exactitude, de la mise à jour et de la fiabilité du contenu de ces sites. La SCA n'offre aucune garantie à cet effet et se dégage de toute responsabilité concernant l'information trouvée par le biais de ces liens. Elle n'endosse pas non plus nécessairement les sites ou leur contenu. Cette liste contient l'adresse de sites qui sera mise à jour de façon périodique. Afin que vous puissiez maintenir une liste à jour, elle est disponible à l'adresse suivante: http://www.cas.ca/Francais/Guide-d-exercice. 
Annexe 5: Exposé de principe sur les assistants en anesthésie: exposé de principe officiel de la Société canadienne des anesthésiologistes

(disponible en matériel électronique supplémentaire Annexe 5)
Annexe 6: Exposé de principe sur la sédation consciente: exposé de principe officiel de la Société canadienne des anesthésiologistes

(disponible en matériel électronique supplémentaire Annexe 6) 